\title{
AUTHENTICITY, IDENTITY AND SUSTAINABILITY IN POST-WAR IRAQ: RESHAPING THE URBAN FORM OF ERBIL CITY
}

Rebwar Ibrahim

Sabah Mushatat

Mohamed Gamal Abdelmonem
Department of Architecture and Built Environment University of Wolverhampton, Wolverhampton, UK e-mail : rebwar_i@yahoo.com

Department of Architecture and Built Environment, University of Wolverhampton, Wolverhampton, UK e-mail : $\underline{\text { S.Mushatat@wlv.ac.uk }}$

School of Planning, Architecture and Civil Engineering, Queen University, Belfast, Northern Ireland e-mail :.n.gamal@qub.ac.uk

Received: August $22^{\text {nd }} 2014$; Accepted: October $9^{\text {th }} 2014$; Available Online: December $15^{\text {th }} 2014$

\begin{abstract}
Issues of authenticity and identity are particularly significant in cities where social and cultural change is shaping active transformation of its urban fabric and structure in the post-war condition. In search of sustainable future, Iraqi cities are stretched between the two ends of the spectrum, authentic quarters with its traditional fabric and modern districts with their global sense of living. This paper interrogates the reciprocal influences, distinct qualities and sustainable performance of both authentic and modern quarters of Erbil, the capital of the Iraqi province of Kurdistan, as factors in shaping sustainable urban forms for Iraqi cities. In doing so, the paper, firstly, seeks to highlight the urban identity as an effective factor in relation to sustainable urban form. Secondly, the city of Erbil in Iraq has been chosen as a field study, due to its regional, social, political and historical role in the region. Thirdly, the study emphasises the dynamic activities and performance of residential projects according to rational sustainable criteria. The research concludes that urban identity and the sense of place in traditional and historical places should inform design strategies in order to achieve a more sustainable urban context.
\end{abstract}

Keywords: urban identity, sustainable urban form, Erbil, built fabric, traditional districts, Iraqi cities.

\begin{abstract}
Abstrak
Isu keaslian dan identitas menjadi bagian signifikan di kota-kota di mana terdapat perubahan secara sosial dan budaya yang membentuk perubahan besar pada struktur perkotaan menjadi kota fabrikasi pada kondisi pascaperang. Dalam usaha untuk menjadi kota yang berkelanjutan, kota-kota Irak yang membentang antara dua ujung spektrum, merupakan perpaduan antara area fabrikasi tradisional dan area modern dengan karakter global pada hunian mereka. Makalah ini menggali pengaruh timbal balik, kualitas yang berbeda dan tampilan yang berkelanjutan baik dari area asli maupun modern dari Erbil, ibukota provinsi Irak Kurdistan, sebagai faktor dalam membentuk kota yang berkelanjutan untuk kota-kota di Irak. Pada tahap awal, makalah ini menyoroti identitas perkotaan sebagai faktor yang efektif dalam kaitannya membentuk kota yang berkelanjutan. Kedua, kota Erbil di Irak telah dipilih sebagai objek studi, karena wilayah tersebut berperan dalam bidang sosial politik serta sejarah. Ketiga, penelitian ini menekankan pada kegiatan dinamis serta tampilan proyek-proyek perumahan yang sesuai dengan kriteria berkelanjutan yang rasional. Hasil penelitian ini menyimpulkan bahwa identitas perkotaan dan kesadaran akan tempat-tempat tradisional yang bersejarah harus memberikan strategi desain untuk mencapai konteks perkotaan yang lebih berkelanjutan.
\end{abstract}

Kata kunci: identitas perkotaan, bentuk kota berkelanjutan, Erbil, bangunan fabrikasi, daerah tradisional, Kota-kota di Iraq

\section{Introduction}

The term "Identity", has for long been the central concern of researchers in urban studies, built environment, architecture, planning sociology, and environmental psychology where it encompasses an essential character related to humanity [1]. Images and appearance influence the sense of place, whereby users can recognise and navigate legible places according to their organisation and rationality of their design [2]. Identity however, is not merely a quality of the physical place, as it fundamentally relates to both activity and personality. Sense of identity relies equally upon the observer's context 
and attitude and not just a unique and memorable place [3]. Urban identity is best recognised in representation beyond time and includes a deep understanding of the characteristics of buildings along with social, cultural, and spiritual contexts. While the prohibited city and its architect in Beijing are associated with spiritual powers, Red Square in Moscow or Westminster in London isengrained to identity of political power. Feelings, observations and memories about the city, in this sense, articulate gradually and piece by piece [4]. This supports how it is important to build up an image of the city, since it comprises a multi-layered historical construction of buildings and streets, as well as being realised through daily observations, engagement, and socio-cultural interaction [5].

Concepts of sustainability and achieving a sustainable urban form have become the driving forces in city planning and urban strategies in recent years. Proposals for green, carbon-free and car-free cities are encouraged in most European and American cities' strategic objectives that are mostly driven by advancement of technology [6]. However, a substantial aspect of sustainable urban fabric is the way which city spaces and culture are integral to their future proposals. Preserving historical and memorable places, enhancing visual characteristics, promoting distinctive images and restoring vernacular tradition have become as important asreducing energy costs, effectively using resources and increasing economic opportunities [7]. Moreover, integrating historical features and traditional characteristics in modern planning has proven effective in maintaining the distinctive character of sustainable cities, and more specifically in places which have a rich history [8]. This is proven as an understudied area in the contemporary planning theory and, in particular, the vital role of urban identity in designing and planning sustainable cities in developing countries has not been in focus recently [9].

Erbil, the historical city in the Northern Province of Kurdistan, Iraq, is passing through rapid urban and socio-political transformation following its growing autonomous status as the capital of this region since 2003. Economic prosperity has allowed the city to accelerate its reconstruction and development enjoying more stability and a safer environment in comparison to other cities in Iraq [10]. The rise in private investments and intensive planning, have been counterproductive when it comes to the traditionally built fabric of this ancient city. These parts of the city are exposed to increasing deterioration, ignorance and lack of attention to their distinctive historical character which is perceived as irrelevant to the sustainable future of the city [11]. In different modern planning, architecture and the new liberal organisation systems of wide-open streets with high-rise buildings of business establishments result in a clear state of randomness and disarray in the physical form, in which both old and new, the traditional and the modern appear alien to each other. Looking at urban identity as key to successful strategies for making places for sustainable development, this paper argues that with addressing urban characteristics and practices of traditional areas of the city, sustainable urban form that is distinctive to Erbil is a realistic and conceivable target. In doing that, the conception of urban identity within a framework to be analysed,and the current urban condition of Erbil city will be discussed. Furthermore, it attempts to interrogate a set of indicators that would inform sustainable urban form and are related to human behaviour within the city districts.

\section{Urban Identity Definitions}

The perception of the built fabric has the value and meaning of different objects and physical relationships that people experience in their daily engagement with the city [12]. Kevin Lynch asserted that the identity of a place can be observed and roughly measured by simple tests of recognition, recall and description [13]. As identity refers to the relationship between the self and the surrounding, scholars and theorists have struggled to offer discrete consensus definition that is objective and overarching [14]. Greene [15], on the other hand, argued that the visual image of the built environment reflects a distinguished identity supported by unique qualities embedded in historical and traditional aspects of the urban fabric. These qualities are mostly seen in the liveability and permeability of a space to incorporate and accommodate socio-cultural practices of interaction, security, engagement and solidarity in communal, yet private manner. These characteristics will eventually be recognised and memorised by people as unique to the place and community [16].

Identity, hence, could be attributed to different positions. Identity, in one perspective, refers to a social and cultural cohesion that relates to "number of things for an urban area and the people that live and work there. It relates to tangible and intangible heritage: buildings, history, and memories" [17]. It is a realisation of a distinctive past to inform a progressive future. However, for Devine, urban identity is characterised by conserving the valuable cultural traditions of people, communities and cities during the executions of urban development [1]. It is not only an expression of an old imageof history, but also the viable meanings that result from the use of buildings through generating multi-layered meanings and memories that shape our perception towards the city individually and collectively [4] [18].

Urban formis understood by the people who engage with its spaces and who add to their reality and liveability on everyday basis. This is noticeable in the traditional districts where the sense of belonging and preservation of community values, principles and practices is relatively high [19]. Urban identity, hence, could be seen in the distinct character that a place or city will have imprinted 
through its past, present and into the future [20]. It is perceived by urban theorists to comprise three important aspects;

- Physical characteristics and appearances which compose the built environment and fabric (static) (buildings and open spaces).

- Activities and Functions which reflect the common interaction between people and how they act and use their physical context (dynamic), and

- Meanings, signs, and symbols which are considered the most complex features of identity since they are related to human behaviour, intentions and experiences (Perceptual). These components and evaluation criteria eventuallyinteract to influence urban identity, and each must be observed, analysed and considered in relation to the others.

\section{Sustainability And Identity}

Sustainable development requires compatible strategies between the physical development and the natural environment preservation taking into account the social and economic issues. Adrian Allen defines sustainable development as "the lasting of city attainments in physical, economic, ecological and social development. The impact on natural resources minimised to a sustainable yield" [21]. A city can be sustainable if the input resources (e.g. land, energy and water) and output resources (e.g. air and solid waste) have been reduced, while the integration of social, physical, economic and environmental elements have improved to secure the quality of life for all generations [22].

Planners have recently focused on improvements in urban structure and enhanced their outcomes by using forms, concepts and historical elements of the old traditional cities in a sustainable mode. For example, Panerai stated that, "The development of Amsterdam is modern, and even progressive, because of its objective, as well as the means set up to achieve it, which included public expropriation and long-term planning. However, these new initiatives were not carried out in defiance of the existing city. Neither in the overall plans nor in the treatment of details is reference to the city forgotten" [23].

These approaches require cautious creativity to ensure that the new design and planning would enhance the characteristics of the old while achieving a holistic strategy for sustainable urban development [24]. The holistic integration between the form and identity, and the historical context of an urban structure would reinforce critical continuity and futurity of the sustainable city.

Consensus in urban planning on achieving sustainability demands compactness, diversity, dense layout and liveability. A liveable city contains an active public realm for reflecting the spirit of itself, for creating and reinforcing a common identity and sense of place, for interchangeable common values and for memorizing its history [8]. In comparing a liveable city to a sustainable city concept, liveable city concept is to be more human centred; a liveable city should be 'healthy, convivial and socially just living, being shaped by the conditions of their natural and urban structure' [25]. Liveable quarter as having strong neighbourhoods and sufficient supporting amenities within walking distance, a network of attractive public spaces and buildings, affordability, cleanliness, and energetic and diverse street culture $^{6}$. In this sense, older cities tend to be remarkably rich in historic buildings, urban intensification andland-use mixture. Moreover, they equally have social, cultural and religious institutions that stimulate behaviour and social life. These traditional elements, unique structures and historic parks significantly define a city's physical character, as they do in Rome, London, and Paris [8]. These aspects were the main characteristics of many other old cities and quarters which have a compact form, mixed-use activities, combined live-work environments and high density dwellings. In addition, living in harmony with nature has been a central part of people's identity, manipulating also the qualities of their built environment.

Heritage areas are, therefore, profound examples of sustainable building traditions and crafts. They were built using local techniques and with locally available materials [14]. In the traditional city, in contrast to the modern, one could rediscover beauty, multiplicity and a rich urban environment which provided the basis for strong identity, spontaneous meetings and social exchange [26]. Scholars and researchers identified various factors, elements and indicators to measure the urban identity of a place. In summary, a holistic framework of the essential urban identity criteria can be organised to apply for the empirical study as per the following table [table 1]

\section{Erbil, Identity And Character}

Erbil is believed to be one of the oldest continuously inhabited cities in the world for more than 6000 years [27] [Figure 1]. The city is the capital of Kurdistan independent region and lies about 350 kilometres north of Baghdad, and is the third-largest city in Iraq after Baghdad and Mosul [28]. Kurdistan urban region includes 130 cities, around $80 \%$ of the total population of Kurds living in the urbanised area, while only $20 \%$ living in the rural. Before the modern era, most cities of Kurdistan region in the north of Iraq shared a distinguished architecture which preserves its common characteristics and local aspects [29]. 
Table 1. Urban Identity of a Place

\begin{tabular}{|c|c|c|}
\hline Components & Criteria & Elements \\
\hline $\begin{array}{l}\text { Physical } \\
\text { Features }\end{array}$ & $\begin{array}{l}\text { Functionality } \\
\text { Urban Form }\end{array}$ & $\begin{array}{l}\text { Land use; Mass } \\
\text { and Void } \\
\text { Skyline; } \\
\text { Topography } \\
\text { Layout and } \\
\text { Pattern; } \\
\text { Location }\end{array}$ \\
\hline $\begin{array}{l}\text { Dynamics } \\
\text { \&Activities }\end{array}$ & $\begin{array}{l}\text { Diversity } \\
\text { Vitality } \\
\text { Accessibility }\end{array}$ & $\begin{array}{l}\text { Street activity; } \\
\text { Liveability; } \\
\text { Interaction } \\
\text { Containment; } \\
\text { self sufficiency } \\
\text { Access and } \\
\text { permeability }\end{array}$ \\
\hline $\begin{array}{l}\text { Meanings and } \\
\text { Symbols }\end{array}$ & $\begin{array}{l}\text { Distinctivness } \\
\text { Socio-Cultural }\end{array}$ & $\begin{array}{l}\text { Image; Visual } \\
\text { Access; } \\
\text { architecture \& } \\
\text { Form } \\
\text { Distinction; } \\
\text { Durability; } \\
\text { Traditional and } \\
\text { Historical }\end{array}$ \\
\hline
\end{tabular}

As seen in Erbil citadel and the traditional quarters that surround it. Strict urban planning and design regulations have contributed to the overwhelming constitutions of the notion of idealist city with compatible, sustainable forms and cohesive structure. Some of these were articulation of religious principles of Islamic urbanism based on issues of cohesion, equality and proximity. However, throughout the twentieth and the twenty-first century war disasters and economic sanctions, new building materials and technology, a prosperous oil economy and the impact of the west on the social life style have had major influences on the identity of the built environment of Kurdistan in general and its capital city Erbil in particular.Erbil's built fabric has been transformed by modern architecture and urban design trends and schemes. This involved creating new diagonal streets in the citadel, grid patterns in the surrounding quarters, eliminating traditional old buildings and constructing new modernised buildings based on the new town planning, codes and regulations [11]. In addition, the city is currently witnessing critical stages development characterised by negligence towards traditional and historical places that for long had shaped its authentic urban fabric [Figure 2].

In post war Iraq, the debate on the role of authentic values, identity and character of its architecture in shaping the future of the country's distinct built environment has been a genuine contest on the aspiration for future. In the context of Erbil, historical fabric was never considered part of the city's sustainable future of government strategies which are mostly devoted to reinforce western visions and projects that materialise the new liberal economy and its capitalist agenda [30].

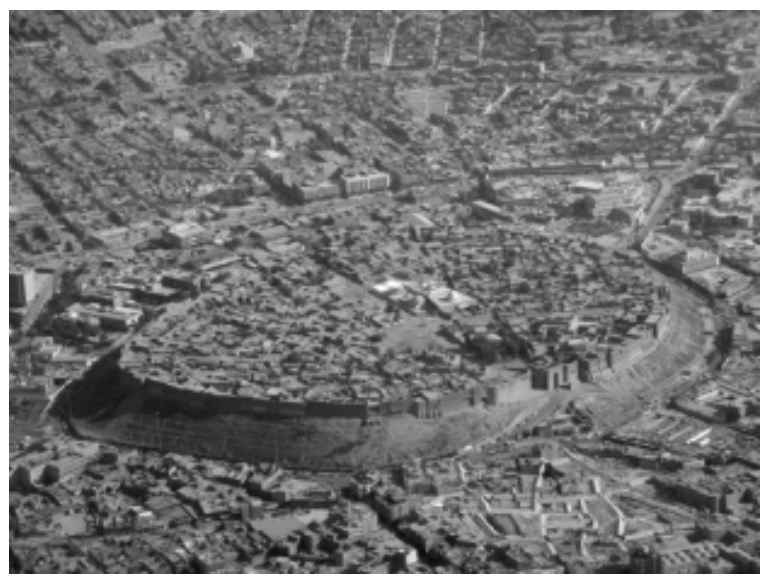

Figure 1: The Citadel of Erbil city, Iraq

Source: HCECR, 2007

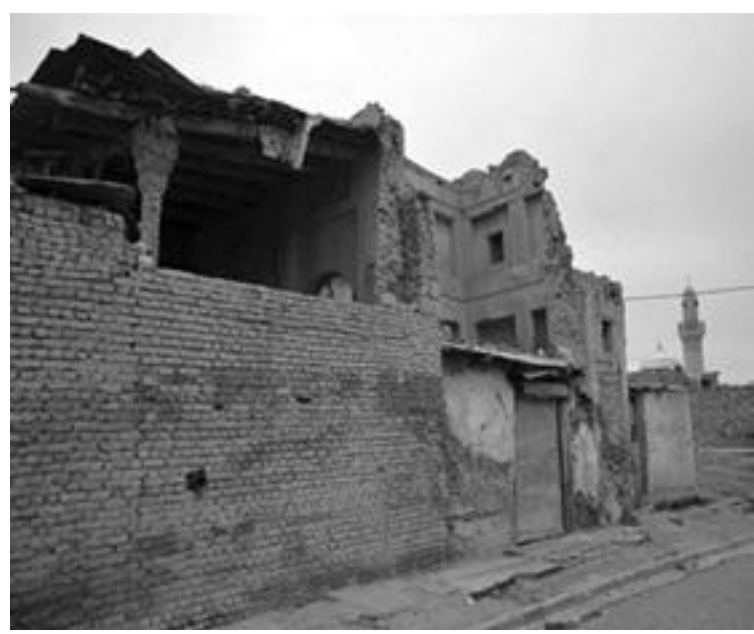

Figure 2: Deterioration of Citadel houses, Erbil

(Source: author)

The Traditional period in the early twentieth century was particularly important in shaping the contemporary city's form and character [Figure 3]. It was distinguished by the unique architectural characteristics and the spatial urban aspects of the ancient city. Besides, it can be recognised as vast and compact units of buildings, local and simple materials of bricks and woods, from one to two floors, narrow and intimate streets that preclude motorised transport and enclosed by town walls [10]. Whereas, in comparison, the current Modern period, is witnessing flourished economical and investment explosion [Figure 4]. Western metaphor and strange contradictions of styles and materials dramatically dominated many buildings and recent urban projects. These factors influence both traditional urban identity and modern forms and their adaptation in relation to other components of the urban fabric. 


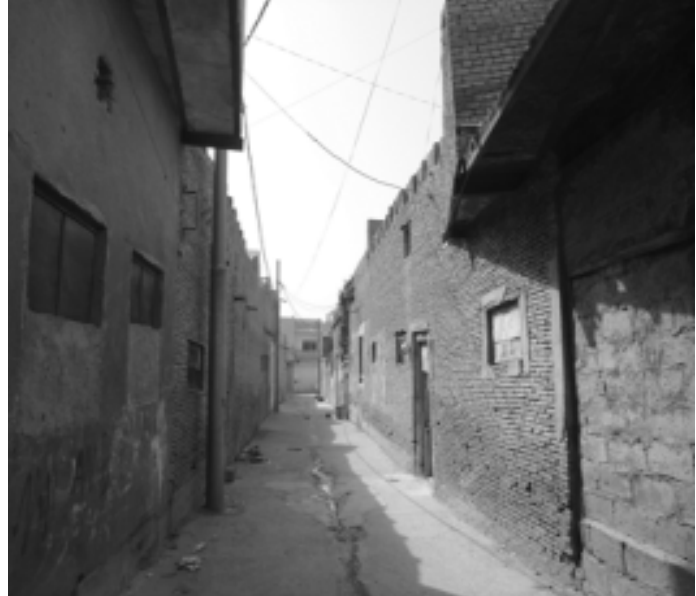

Figure 3: Traditional district, Erbil (Source: author)

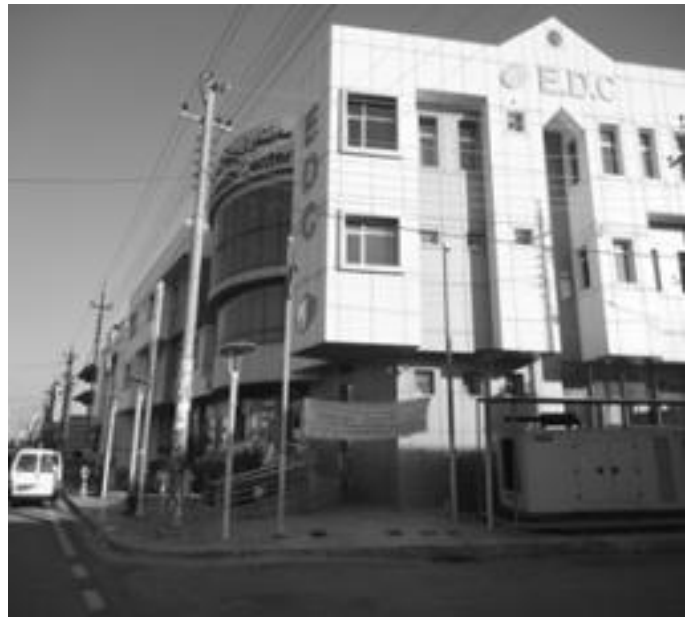

Figure 4: Recent Public Buildings, Erbil (Source: author)

\section{Method And The Case Study}

This research seeks to compare the urban identity of two different residential districts. The first is located in the oldest districts of the innercore of Erbil (Arab district No.1). The second is located approximately 2.5 miles south west of the city centre and in proximity to other post-modern residential projects in Erbil (The Italian Village No.2) [Figure 5]. Case study sites have been chosen to represent contrasting patterns with two distinct identities where the first holds sufficiently rich historical presence [Figure 6], and the second colonises a substantial and recognised location in the city. The inherently dynamic activities, perceptions and quality of both districts are exemplar to their particular modern character and may inspire people who visit, use or inhabit them, to evoke their sense of place and intimate belonging. The interviews with residents, tourists and workers, as well as the observation method, may reveal an interesting variety of insights, opinions and visual exploration which are potentially valuable for establishing various sustainable approaches to the future of the city.

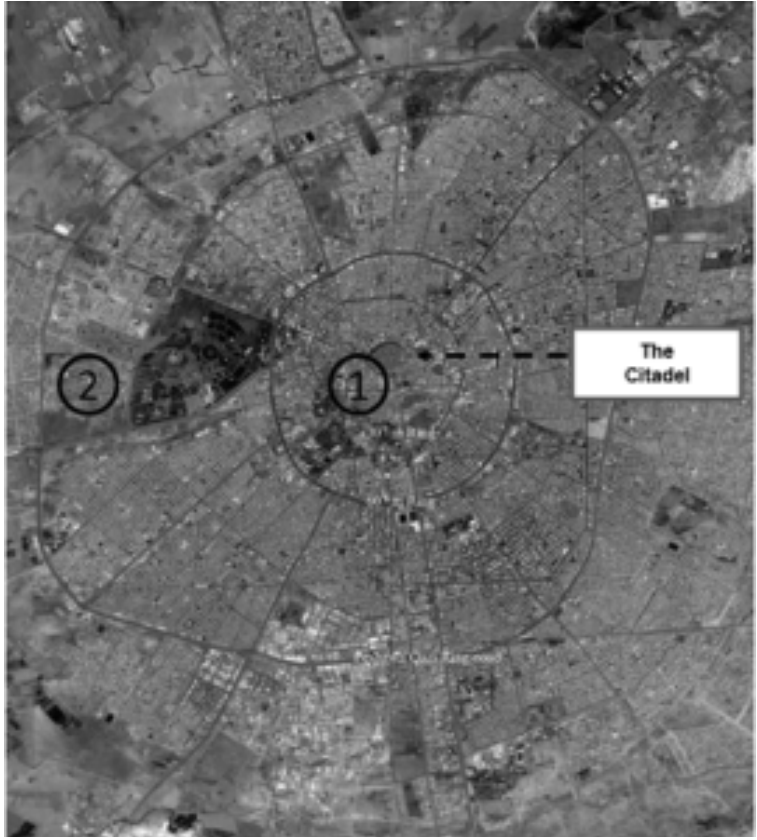

Figure 5: Erbil Map Showing the Two Districts

(Source: KRG, Ministry of Planning, 2007)

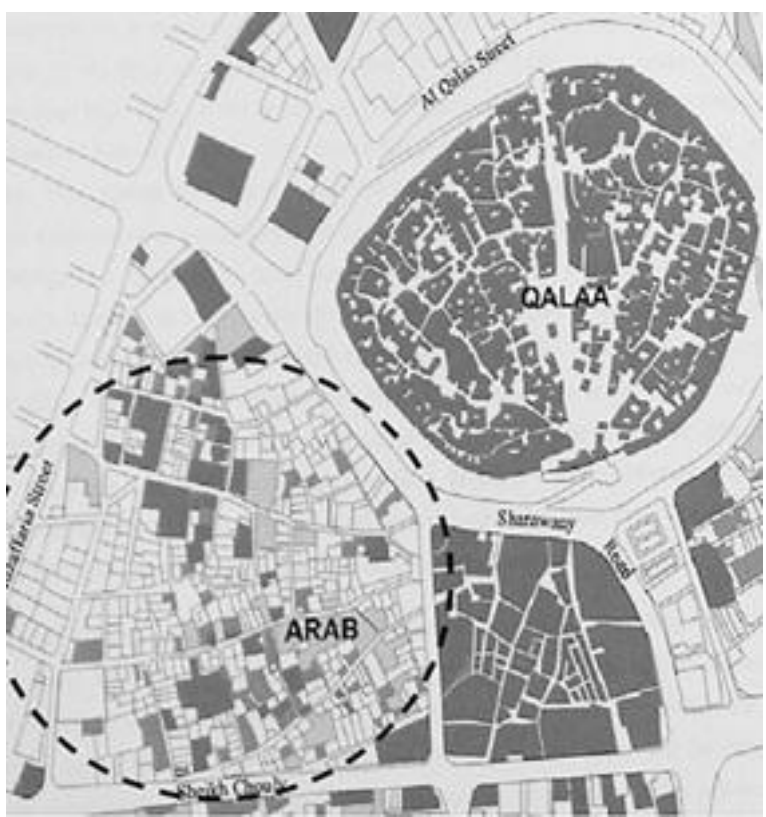

Figure 6: Location of Arab District, Erbil

(Source: Dar-alhandasa, 2006)

Human activities have a strong impact in exploring and revitalising the sense of place. Vitality means the liveliness of a place, it is about delightful and desirable urban spaces that offer and reflect cultural and sacred enrichment [24]. Diversity and the creation of some sort of identity for an inclusive environment are important and possibly crucial for being sustainable [31]. Walk ability and permeability are central to this research as they provide the movement and the social interaction of community well as they are essential criteria of a sustainable built environment [32]. Community social interaction enhances the quality of life and place [33]. In 
addition, activity containment refers to its functional and physical reliability to ensure the development of a process without impinging the others. The results are based on field observations and interviews with constant users (residents and office workers), and mobile users (visitors and tourists). The selection of interviewees was carefully planned, particularly the Elderly residents of both districts. The people were selected on the basis of having different background and ages. Interviews are performed with both constant users and mobile users in the Arab district (50 samples) and a similar number in the Italian village.

The Arab District took its name from Arab immigrants who went to the city of Erbil, lived and settled in this part of the city. This neighbourhood is located in the western part of the castle, and considered one of the oldest settlements outside the castle. Open spaces and pedestrian paths are integrated in an urban form similar to any traditional cities as the basic components of urban fabric articulate in clusters that avoid wasting spaces in the whole urban networks [34]. Most of the dwellings are made of one floor (bricks) and built in traditional terms where it contains the courtyard (Al-Hosh) in the centre of the unit is surrounded by rooms on all sides. The geometrical shape is either square or rectangular with one entrance and one window or more depending on its span. There is also another type of dwelling which is bigger and consists of two floors with more rooms and openings. All the units articulate contiguous and compacted blocks with narrow organic alleys which provide the significant environmental and social protection [Figure 7-8]. This quarter is clearly defined by larger streets (AlMuzafaria and Sharwany streets) that include mixeduse activities. This priority aspect provides easy access from the district to the facilities of the central city.

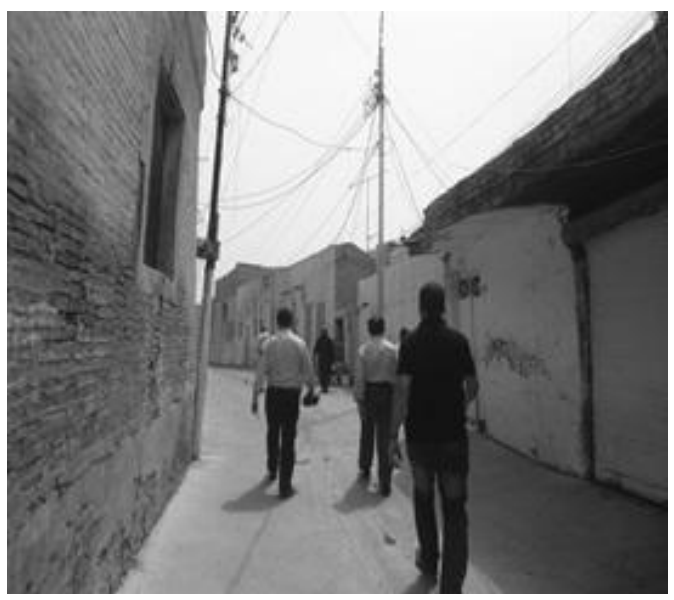

Figure 7: An inhabitant street, Arab District

(Source: author)

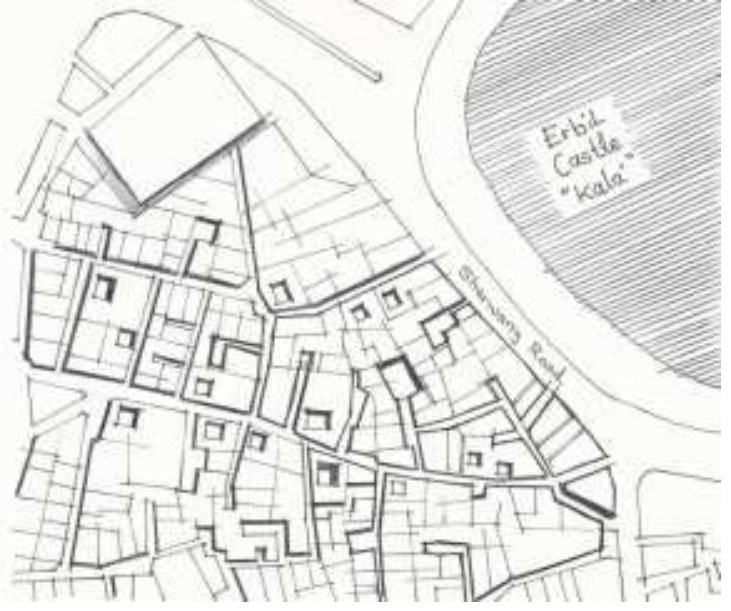

Figure 8: Urban Configuration, Arab District

(Source: author)

Demographically, the population density is considered high compared to inhabited dwellings (Average 5 persons/ family). Most young householders and family members have permanent jobs to afford their living. Socially, despite the unstable gradient of physical condition, social gathering among the neighbours in the alleys is still popular. However, the lack of proper open spaces, children's play-zones and appropriate car parking are the most common defect features regarding this quarter.

The Italian Village, the Italian Village was constructed by Hemn Group in 2008, and comprises 659 housing units and has attached and semidetached units [Figure 9]. The project consist of two types of housing for residential, local and international offices, (two-floor buildings) besides, it contains many public services (one floor buildings) like a primary school, shops and a mosque. The planning concept based on a tree shape taking into consideration the separation between private zones (residential) and public zones (offices and services) through linear and grid pattern inner streets [Figure 10].

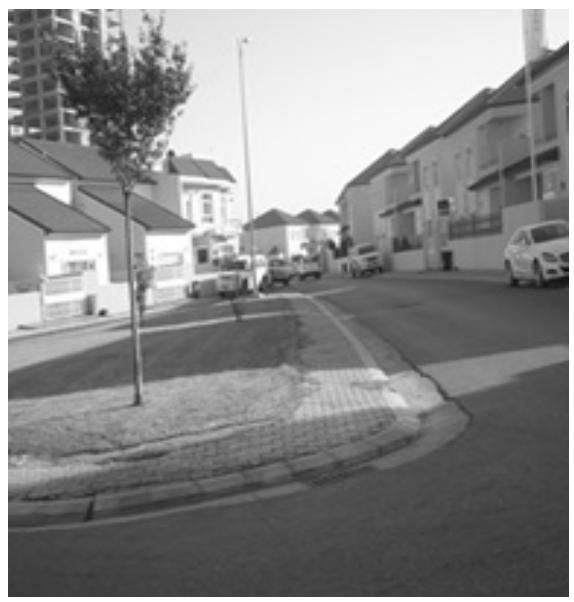

Figure 9: Various Types of Houses

(Source: author) 


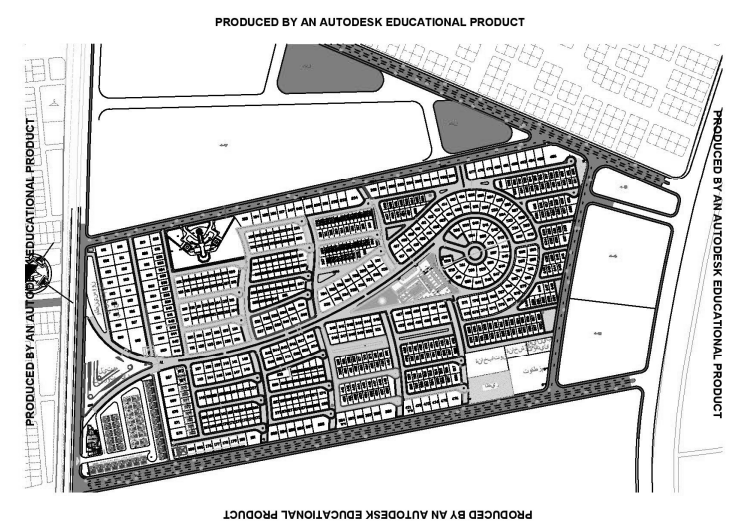

Figure 10: Italian Village Site

(Source: Hemn Report, 2006)

The project is regarded as a modern walled residential campus to provide privacy, security and uniqueness. Most of the residents can be classified as high-income families. Though this quarter is localised between two major collectors $(100 \mathrm{~m}$ Ring Road and Gulan streets), its social- accessibility isolation remains high grade due to its site planning design and the secure wall. Population density is less than the first quarter (Average 4 persons/family). The open spaces and green areas are well defined but, the lack of parking plots is still a common required aspect.

\section{Understanding Local Perceptions Of Urban Identity}

The residents' sample in the Arab district reflects responses related to feelings of attachment to the place and sense of belonging to each building, street or heritage that cling to the past to inform the future.

"I've been living here for more than five decades, though many of my neighbours had left looking for a better place, I intend to spend the rest of my life here. My childhood, memories, and my family heritage belongs here", says an old resident in Arab district. "I have unlimited compassion for such places, It reminds me of my old quarter in Baghdad, where I was born", says another.

In contrast, socio-economic problems, the lack of maintenance and services (infrastructure), are considered major issues that constitute elements of gradual deterioration of this essential part of the city. Moreover, mixed used facilities began to vanish and the liveability of the district decreased dramatically. According to one resident, this started to affect the social cohesion and the sustainable nature of the place; he asserted

"I used to go out and enjoy my time with friends and brothers in these remote coffee shops, but now the majority has disappeared due to residents' immigration and buildings bad conditions".

Concerns and advantages of living in the Arabian district, seems to go in the opposite direction for the Italian District. According to the interviewed residents of the Italian village, the sense of identity and distinctiveness is dramatically limited when they compare it to their previous houses in the city, however, mostly they expressed positive appreciation regarding the quality of their new residences and provided services.

"I enjoy my life here, everything is available, the services are very good compared to my old neighbourhood", says a middle-aged resident.

Nevertheless, Issues of identity and authentic living seem diminished in their responses due to various reasons, one of which is their mobility and engagement in place-less venues, since most of these upper-class people. To gain this sense of authenticity and nativeness, they move back regularly to families and friends in old districts, where they grew. One resident asserted this viewpoint saying:

"I like to spend the holidays with my parents and old friends, there where I lived before".

Considering overwhelming patterns of modern life for those engagement with modern businesses, office workers, businessmen and those in the higher bureaucratic order, are attached to their workplaces more than their residential and living context neighbourhood.

"I come to work early in the morning to avoid the rush traffic, and leave late. So, I don't have such a feeling of belonging to this place", says an office worker.

Using private vehicles is the common character in these districts due to the lack of daily needed facilities. In addition to poor viability, most residents express concerns about their unliveable community. These issues for a socially-cohesive society, mean support to children and wives is rather limited, depriving them from essential needs and local cultural training.

"Residents prefer staying at home after 8 p.m., there is no entertainment here, we have asked the relevant authority for help, but there is no response", says an adult who was preparing to leave the compound.

Observation of walk ability and vehicle mobility in both places shows evident findings due to many factors like street pattern and condition, economical state of users, permeability value and the distance to the city centre or work places. The average pedestrian movement (constant and mobile users) scored high percentages in the Arab quarter [Figure 11] compared to those in the Italian. However, the figures for vehicles movability in the Italian zone clarify extreme differences related to the historical quarter. In the traditional district, the narrow winding paths (3-4 metres) reinforced security and sense of belonging, but in contrast, in the modern, the wide and amenity paved streets (8-12 metres) support the high flow of vehicles [Figure 12]. 


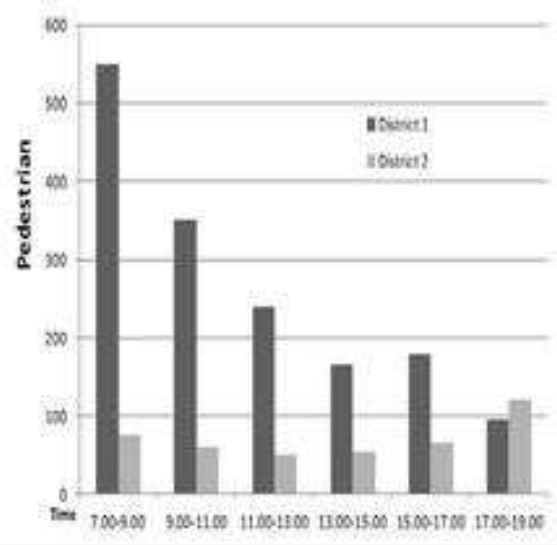

Figure 11: Pedestrian movement in the main routes (Source: author)

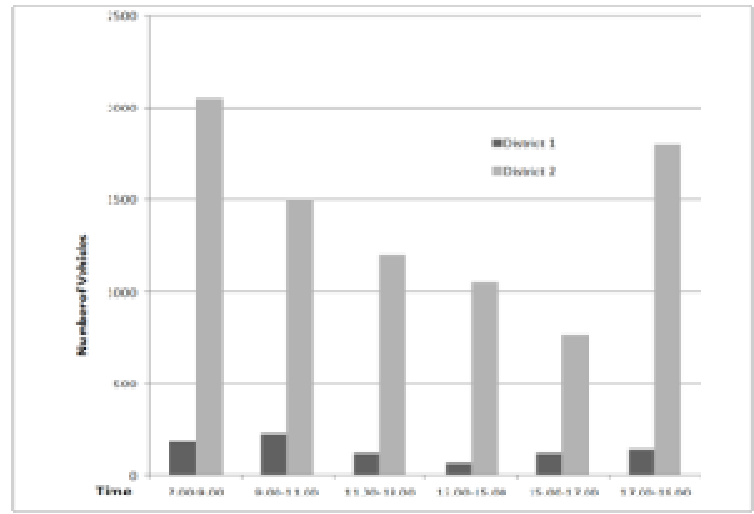

Figure 12: Vehicles Mobility in the main streets (Source: author)

Diversity and mixed use activities mean that all destinations are close and integrated. This is one of the important principles in modern sustainable design of neighbourhoods. Though there are few educational, religious and public buildings which resist the flabbiness of the structure in the traditional zone. The spirit and place of diverse activity has changed its local nature and authenticity, nevertheless, the district still has its own character and attractions for many people. Unfortunately, activities like promenade and shopping have been moved to other adjacent or remote districts to enhance nightlife attractions and preserve the identity characteristics. On the other side, the public mosque and the mini market which centralise the Italian neighbour are not enough to make the place flourish.

In social places, individuals use spaces to build their identities and self-images. Social interaction and relations enhance and sustain the characteristics of urban identity and sense of intimacy and belonging. There is an essential contradiction between the two districts regarding permeability and social interaction. In the Arab quarter organic, hierarchal and permeable spaces and the physical access to adjacent quarters while controlled and always monitored, increase the sense of community and interaction with local neighbours. In contrast, in the Italian village, the high walled fence, the type of grid-linear streets and the attached units impair social interaction. The unification of style and image, the modular and regular pattern and the typicality of design style have collectively weakened the sense of community and give the impression of unwillingness to sustain aspects of distinctive sense of place. The value and the quality of any space are built on our concrete images, experiences and senses of places. The sense of containment and enclosure in the traditional quarters is visible and well defined in the nodes and semi-public spaces (intersections of two or more paths) and in the dead-end streets.

The value and the quality of any space are built on our concrete images, experiences and senses of places. In this sense, there is a strong and legible social hierarchy in the traditional space system where it is expressed in the layout of street-nodedwelling integration. The sense of containment and enclosure in the traditional quarters is visible and well defined in the nodes and semi-public spaces (intersections of two or more paths) and in the deadend streets. These spatial cores are utilised to interact and accomplish certain residential, commercial and sometimes industrial activities thus result into a mixed land use pattern and combine the social and physical context. Moreover, many writers have made a point that providing community's safety and security is an important dimension of social sustainability. Dempsey quotes

"There are a number of interrelated concepts and dimensions which make up sustainability of community: social interaction and networks, participation in groups and networks, community stability, sense of place, safety and security" [35].

Feeling safe means people can have a strong sense of attachment and commitment towards their built environment. Abdelmonem investigates these characteristics in the traditional alleys of old Cairo [Figure 13] and states

"Each harah is characterised by the spatial order of its shared public space - the alleyway - as bounded by its entrances/ gates and lined by attached low-rise houses, But it is also defined by a distinct social structure, cultural identity, and shared responsibility for local security" [19]

These social activities and proximity enhanced the sense of security, visibility and surveillance encouraging mixture of uses, social cohesion and integration of a wide range of the cultural spectrum to maximise a presence and sense of ownership at all times. Social safety and security are considered significant factors in the perception of sustainability [14]. In the historical patterns of Arab district, these organic configurations help gradually unfold the spaces and introduce an element of surprise. The focal point of the narrow street is located in these nodes or the outlet spaces of the street.

"It is not merely a space for transportation or passing by, but the one for work, commerce, play, visit, gathering ceremonies, festivals and other social events, beside, our 
neighbour's collective and intimate memories", says an old resident.

"It is the place where we continue our social interaction and engagement activities with our neighbours and my children feel safe and secure to play here", adds a middleaged mother. Another passing-by visitor states "When we moved away from here, the avenue, we missed it. It wasn't the same. Here, everyone was watching each other's kids...you know, it's just looking out for each other. If you have a community with each other you feel safer, you're free".

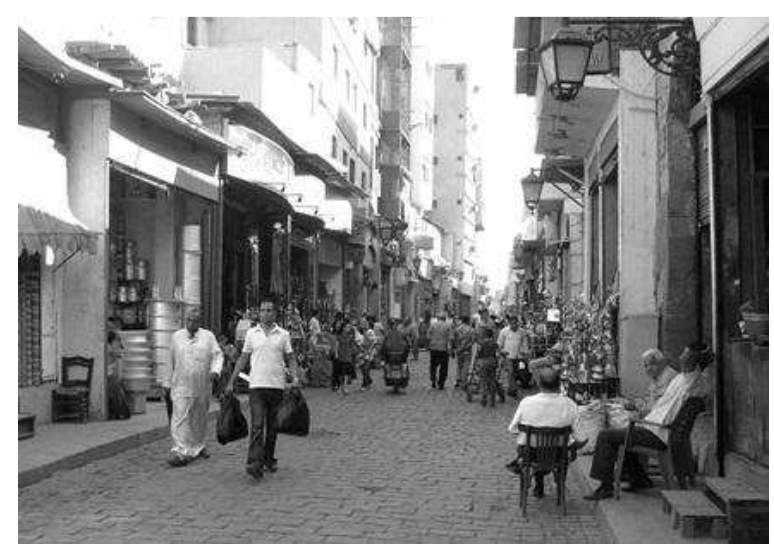

Figure 13: Social cohesion in Old Cairo: Integration of Social, Commercial and Industrial worlds in Shared Responsibilities in Everyday Life

(Source: author)

On the other hand, in the Italian district, patterns of new spatial arrangement based on the "urban rationality" of the modern planning practices are being grossly applied to the existing built environments without actually understanding its adaptability to the local context. The wide and continuous grid streets become more vehicular and ignore the intimate enclosures that accumulate resident's images and events.

"We gather here, in this intersection, for one hour or more whenever we have the chance, it is a normal plot like others in the camp" says an adult resident.

However, the high security wall gives the safety impression among most of the residents. "I think it is safer to dwell here with this high protection barrier", applies a relative middle-aged lady. Consideration of these physical barriers is not required in the heart of the city, which is continuously observed, monitored and well attended. While the walls could be preached at times, the uninterrupted shared security provisions in the dense city fabric of Erbil seem yet to lose its chief advantage. Yet again, Jane Jacob's notion of the safe communities in the liveability of their streets seems a viable reference to the shear contrast in perception and practice of everyday life in the City's two contrasting urban environments [36]. The Sustainability of the urban context of Erbil would inevitably require integration between the two patterns of living across the city.
Urban Identity, Sustainability And The Future Of Erbil

Post war Iraq passed through unstable sociopolitical condition following decades of oppression and undemocratic rule. Under authoritarian regimes, modernising the urban landscape through new planning schemes that imitate western models have largely dominated the dominant top-down vision to change the character of traditional urban fabric in Erbil as most of the Iraqi cities in the second half of the twentieth century. The creation of European villages was hence removed from the quality, liveability and environmental coherence of the traditional landscape. Modern quarters and suitable forms to modern lifestyle were always a need for twentieth century cities, the imitation of alien models with foreign characters. Yet, a sustainable urban fabric requires a mitigation of shortcomings of the foreign models to match local needs and proximities to everyday life in the Iraqi city of Erbil.

Urban identity cannot be judged exclusively on the coherence and modernity of its physical characteristics, but it articulates holistic components of socio-cultural, historical, environmental, behavioural and political elements. Urban planning and design as a part of sustainable development strategy has strong commitment to create places which acquire a unique meaning and sense of identity in order to accomplish an ideal sustainable urban context. These could appear in sophisticated and centuries-old quarters of the city more than modern plans with their social engineering approaches. In this sense, the historical inner city districts of Erbil that are characterised by narrow street patterns and pedestrian paths with high level of densification and mixed activities seem to offer unique and distinctive qualities that contribute to sustainable performance which modern districts failed to achieve. Parts of residential quarters have been rehabilitated and transformed for commercial activities due to the decline in physical condition as a result of their inadequacy for habitation. Nevertheless, dynamic elements of urban identity, especially liveability, containment and permeability played an important role in helping residents to identify their territories.

Taking into account inherent qualities of the dense landscape of the old city and its sociallyintensive fabric, local urban planning vision needs to adopt flexible approaches that accommodate qualities that were genuinely integrated in everyday life in local quarters. Local planning authorities need to take responsible steps towards enhancing the sense of urban identity to achieve a better sustainable development in Erbil City. Integral to this strategy is to rescue the valuable historical and cultural heritage from deterioration through encouraging and supporting the distinctiveness of urban identity through:

Preserving Architecture and built fabric components that have historical and cultural 
heritage value; the more distinctive buildings are, the stronger is their identity to the residents.

Promoting the liveability of the old parts of Erbil city and adopting a holistic approach to the understanding of traditional urban forms which enhance and enrich the spirit and identity of new developments.

- Identification of urban priority locations to make these distinguishing places more visible and accessible, especially by integrating proximity to workplaces as effective sustainable strategy. This provides high quality interaction nodes, vibrancy, and intimate containment.

Enhancing community spirit through mixed-used development and pedestrian friendly streets which is considered an essential dimension of sustainable urban form. By creating such areas, local facilities become more viable, spatially liveable and maintain continuous traffic that is needed for active protection and surveillance.

This paper aimed to explore the essence of quality and urban identity from the perceptions of local residents in two distinctive districts in the city of Erbil. It emerged that while many regulations, resources and functionality of modern design were at work in the planning and design of the late 20th century until today, there are missing qualities on aspects of liveability and permeability that this empirical research confirmed to be peculiar to the old city fabric.

\section{References}

[1] P. Devine-Wright, "RethinkingNIMBYism: The Role of Place Attachment and Place Identity in Explaining Place-protective Action," J. Community Appl. Soc. Psychol., vol. 19, pp. 426-441, 2009.

[2] K. Lynch, the Image of the City. Cambridge: MIT Press, 1994.

[3] M. Southworth, Place, Identity and the Global City. New York: Routledge, 2010.

[4] D. Oktay, "How Can Urban Context Maintain Urban Identity and Sustainability?," in the International Conference for Integrating Urban Knowledge and Practice, 2005.

[5] C. Popescu, "Space, Time: Identity'," Natl. Identities, vol. 8, no. 3, pp. 189-206, 2006.

[6] H. Girardet, Cities People Planet: Liveable Cities for a Sustainable World. Chichester, UK: John Wiley and Sons, 2004.

[7] P. Newman and I. Jennings, Cities as Sustainable Ecosystems, Principles and Practices. Washington: Island Press, 2008.

[8] J. Kriken, P. Enquistand, and R. Rapaport, City Building, Nine Planning Principles for the Twenty-First Century. New York: Skidmore, Owings \& Merrill, 2010.
[9] L. Vale and S. Warner, Imaging the City. New Jersey: Centre for Urban Policy Research, 2001.

[10] S. Yasin, "Influence of Modernity versus Continuity of Architectural Identity on House Facade in Erbil City, Iraq," University of Sains Malaysia, 2011.

[11] H. Nooraddin, "Architectural Identity in an Era of Change," Dev. Ctry. Stud., vol. 2, no. 10, pp. 81-96, 2012.

[12] J. Tomlinson, "Globalization and Cultural Identity," in The Global Transformations Reader, D. H. A. McGrew, Ed. Cambridge: Polity Press, 2003, pp. 269-272.

[13] K. Lynch, Good City Form. Cambridge: MIT Press, 1982.

[14] E. Shawesh, "the Changing Identity of the Built Environment in Tripoli City Libya," University of NewcastleUpon Tyne, 2000.

[15] S. Greene, "City Shape: Communicating and Evaluation of Community Design," APA J., vol. 58, no. 2, pp. 177-189, 1992.

[16] S. Shamsuddin, "Identity of place, A Case Study of Kuantan town centre, Malaysia," University of Nottingham, 1997.

[17] M. Al-Naim, "Identity in Transitional Context: Open-ended Local Architecture in Saudi Arabia," Arch net- IJAR, Int. J. Archit. Res., vol. 2, no. 2, pp. 125-146, 2008.

[18] M. G. A. Monem and G. Selim, "Architecture, Memory and Historical Continuity in Old Cairo'," J. Archit., vol. 17, no. 2, pp. 167192.

[19] M. G. Abdelmonem, "the Practice of Home in Old Cairo: Towards Socio-Spatial Models of Sustainable Living," TDSR, vol. 23, no. 2, pp. 35-50.

[20] M. Gurel, Domestic Space, Modernity, and Identity: The Apartment in Med 20th Century Turkey. University of Illinois: Urbana Champaign, 2007.

[21] A. Allen, "Urban Sustainability under Threat: The restructuring of the fishing industry in Mar del Plata," Argentina Dev. Pract., vol. 11, no. 2-3, pp. 152-173, 2001.

[22] P. Newman and J. Kenworthy, Sustainably and Cities: Overcoming Automobile Dependence. Washington: Island Press, 1999.

[23] P. Panerai, J. Castex, J. Depauleand, and I. Samuels, Urban Forms, the Death and Life of the Urban Block. Oxford: Architectural Press, 2004.

[24] A. Bertaud, "Institute of Urban and Regional Development," California, 2004, 2004.

[25] V. Timmer and N. Seymoar, "The Liveable City," in A paper submitted to the world urban forum, International Centre for Sustainable Cities, 2003.

[26] L. Marcus, Architectural Knowledge and Urban Form, the Functional Performance of Architectural Urbanity. Stockholm: Point line $A B, 2000$. 
[27] A. E. J. Morris, History of Urban Form: before the Industrial Revolution. New York: Wiley \& Sons, 1994.

[28] KRG, Ministry of planning, Regional statistical office. Erbil: statistic year book, 2007.

[29] K. Yildiz, The Kurds in Iraq the Past, Present and Future. London: Pluto Press, 2004.

[30] A. Ismail and I. Ngah, "Urban Planning for Small and Medium Cities in KurdistanRegionIraq," Int. J. Eng. Sci. Technol., vol. 2, no. 12, pp. 7070-7077, 2010.

[31] E. Talen, Design for Diversity, Exploring Socially Mixed Neighbourhoods. New York: Elsevier, Architectural Press, 2008.
[32] B. Durmaz, "Creative Clusters and Place Making: Analysing the quality of place in Soho and Beyoglu," University of Nottingham, 2012.

[33] D. Farr, Sustainable Urbanism, Urban Design with Nature. New York: Wiley and Sons Inc., 2008.

[34] S. Bianca, Urban Form in the Arab World: Past and Present. New York: Thames \& Hudson.

[35] N. Dempsey, G. Bramley, and C. Brown, "The Key to Sustainable Urban Development in UK Cities, the Influence of Density on Social Sustainability'," Prog. Plann., vol. 6, no. 77, pp. 89-141, 2012.

[36] J. Jacobs, the Death and Life of Great American Cities. New York: Random House Inc., 1989. 